\title{
Effect of Monoculture and Polyculture Systems on Growth and Production of Fishes in Seasonal Waterbodies of Haor Villages, Sunamganj District
}

\author{
M. S. Ali ${ }^{1}$, M. S. Islam ${ }^{1^{*}}$, N. Begum ${ }^{1}$, I. N. Suravi ${ }^{1}$, M. Mia ${ }^{1}$, M. A. Kashem ${ }^{2}$ \\ ${ }^{1}$ Department of Coastal and Marine Fisheries, Sylhet Agricultural University, Sylhet-3100, \\ Bangladesh \\ ${ }^{2}$ Department of Soil Science, Sylhet Agricultural University, Sylhet-3100, \\ Bangladesh
}

Received 12 February 2017, accepted in final revised form 20 May 2017

\begin{abstract}
The study was conducted to assess the growth and production of Thai sarpunti (Puntius gonionotus), tilapia (Oreochromis niloticus) and rui (Labeo rohita) under monoculture and polyculture systems in seasonal waterbodies of haor environment. Selected waterbodies were divided into three treatments as $T_{1}$ (sarpunti), $T_{2}$ (sarpunti+tilapia) and $T_{3}$ (sarpunti+tilapia+rui). Each treatment had three replicates and same stocking density $\left(40,000 \mathrm{ha}^{-1}\right)$ of fishes was maintained in all treatments. Stocked fishes were fed with rice bran and wheat flour as supplemental feed at a decreasing rate of $10-5 \%$ of total biomass for twice daily. The highest final weight of sarpunti (122.32 g), tilapia (102.58 g) and rui (140.0 g) was obtained in $T_{1}, T_{2}$ and $T_{3}$, respectively. Significantly higher production of sarpunti was secured in $\mathrm{T}_{1}\left(3,446.13 \mathrm{~kg} \mathrm{ha}^{-1}\right)$ than $\mathrm{T}_{2}\left(2,942.6 \mathrm{~kg} \mathrm{ha}^{-1}\right)$ and $\mathrm{T}_{3}(2,804.1 \mathrm{~kg}$ $\left.\mathrm{ha}^{-1}\right)$, and tilapia production was better in $\mathrm{T}_{2}\left(2,786.07 \mathrm{~kg} \mathrm{ha}^{-1}\right)$ than $\mathrm{T}_{3}\left(2,172.52 \mathrm{~kg} \mathrm{ha}^{-1}\right)$. Combined production of sarpunti, tilapia and rui was significantly $(\mathrm{p}<0.05)$ higher in $\mathrm{T}_{3}$ $\left(8,341.41 \mathrm{~kg} \mathrm{ha}^{-1}\right)$ followed by $\mathrm{T}_{2}\left(5,728.67 \mathrm{~kg} \mathrm{ha}^{-1}\right)$ and $\mathrm{T}_{1}\left(3,446.13 \mathrm{~kg} \mathrm{ha}^{-1}\right)$. Therefore, polyculture practice of sarpunti, tilapia and rui may be suggested to disseminate at farmers' level for boost up fish production.
\end{abstract}

Keywords: Monoculture; Polyculture; Seasonal waterbodies; Production; Cost benefit ratio.

() 2017 JSR Publications. ISSN: 2070-0237 (Print); 2070-0245 (Online). All rights reserved.

doi: http://dx.doi.org/10.3329/jsr.v9i3.31531 J. Sci. Res. 9 (3), 307-316 (2017)

\section{Introduction}

Bangladesh is blessed with a vast inland water bodies in the form of small ponds, seasonal ditches, beels, haors, baors, canals, lakes, estuaries and small and large rivers. There are 411 haors comprising an area of about $8,000 \mathrm{~km}^{2}$ dispersed in greater Sylhet (Moulvibazaar, Hobiganj and Sunamganj) including Netrokona, Kishoreganj and

* Corresponding author: islamms2011@yahoo.com 
Brahmanbaria districts. The inland fisheries contributed $83.72 \%$ to total catch (inland capture $27.79 \%$ and inland culture $55.93 \%$ ) and remaining $16.28 \%$ come from the marine fisheries. About $11 \%$ of the total population depends on fisheries for their livelihood [1].

Polyculture of fishes plays a vital role for nutritional and economical aspects in the country. Proper aquaculture as a whole and high density fish culture using supplementary formulated feed is not very much popular in Bangladesh. Small farmers constitute the bulk of the population in Bangladesh and there is urgent need to improve the efficiency of utilization of limited resource base of these small farmers. Most of the rural farmers have various types to waterbodies such as seasonal mini ponds, ditches and canals which retain water for 5 to 6 months in a year. Farmers can effectively utilize these water areas for fish culture either for their subsistence or as commercial enterprises. To minimize the growing gap between demand and supply of fish, feed ingredients or farm made feed/ commercial feeds and fertilizers should be used for increasing production of fish. Mixed culture of several fast growing species such as mirror carp (Cyprinus carpio), tilapia (Oreochromis niloticus), koi (Anabus testudineus), Thai sharpunti (Puntius gonionotus), rui (Labeo rohita) and silver carp (Hypophthalmichthys molitrix) of different feeding habits and behaviour can utilize properly the above mentioned waterbodies. Mixed cultures can even show symbiotic effects, when one species improves the environmental conditions and food supply for others. Natural feeds of all layers of a waterbody are properly utilized in polyculture system. On the contrary, in monoculture system those feeds are not utilized accordingly.

Sarpunti, tilapia and rui are significantly contributing in total fish production of the country. These species are very popular as food and they have efficient feed utilization capacity. Fast growing fishes can adapt to poor water quality conditions (low oxygen, low water depth, wide range of temperatures). Haors (natural depressed seasonal and perennial small and large several waterbodies connected with river, canal, stream, etc) of Bangladesh are encompassed by villages. There are many seasonal waterbodies/ditches in these villages. These waterbodies are excavated to raise up the platform of farmers houses. These ditches remain fallow round the year and are covered with water hyacinth and/or other aquatic weeds. These waterbodies are submerged under water about half time of the year due to heavy shower and hilly run off. These are not used for fish culture owing to farmers are not aware to fish culture techniques, lack of fund, non-availability of fish fry and also seasonal nature of the waterbodies. Maximum farmers are poor and they are always busy for fishing and also for boro rice (winter rice) cultivation in the haor. But seasonal waterbodies on the periphery of the haor are very productive. These waterbodies should be brought under fish culture to meet up the demand of animal protein and to boost up the fish production at rural level. Fast growing fish species may easily culture in the seasonal waterbodies. These fishes become marketable size within 4-5 months at minimum feed cost. Keeping these in mind, the present research work was undertaken to utilize the seasonal waterbodies for fish culture and better economic development of the resource poor farmers. 


\section{Materials and Method}

The experiment was carried out for a period of 120 days from January to April 2016 in nine seasonal waterbodies of Noagaon and Robbani Nagor villages situated on the periphery of Dekar haor under Dakhsin Sunamganj upzila of Sunamganj district (Fig. 1). The waterbodies were completely independent and had no inlet and outlet. All waterbodies were randomly numbered. Aquatic weeds of the waterbodies were removed manually. Liming was done in all waterbodies at a rate of $250 \mathrm{~kg} \mathrm{ha}^{-1}$. After one week of liming, waterbodies were fertilized with urea and TSP at a rate of $25 \mathrm{~kg} \mathrm{ha}^{-1}$, respectively. After 6 days of fertilization, waterbodies were stocked with required quantity of fry following the experimental design (Table 1). The fry-fingerlings of fishes were collected from local fish fry traders of Sylhet. The fry of fishes were transported from hatchery to the experimental site with polythene bags having oxygenation facilities. Then fry were acclimatized with water of experimental waterbody and afterwards they were released into the experimental waterbodies. It is mentioned here that the study was designed to stock thai/vietnami koi as a quick growing species under treatment 3 but fry of koi were not available in Sylhet and Sunamganj during the stocking period. Because of this, rui was stocked instead of koi in the selected waterbodies. After stocking of fish in all the waterbodies rice bran $(50 \%)$ and wheat flour $(50 \%)$ were applied at a decreasing rate of $10-5 \%$ body weight twice daily.

Water quality parameters of water such as temperature, transparency, dissolved oxygen (DO), $\mathrm{pH}$, total alkalinity and ammonia were recorded at fortnightly intervals within 09-10 am in each sampling. Water temperature was measured in situ using a standard centigrade thermometer. Transparency was recorded using Secchi disc. Dissolved oxygen was measured using DO meter (YSI digital DO meter, Model 58). pH of waterbody was recorded using $\mathrm{pH}$ meter (manufactured by Hanna Instrumental Company, Japan). Total alkalinity was determined by titrimetric method. Ammonia was measured using ammonia test kit (Biosol, A.A. Biotech PVT LTD., Fishtech BD LTD).

Table 1. Experimental design of the present research.

\begin{tabular}{|c|c|c|c|c|}
\hline $\begin{array}{l}\text { No. of } \\
\text { treatment }\end{array}$ & $\begin{array}{c}\text { No. of } \\
\text { replication/treatment }\end{array}$ & Name of fish species & $\begin{array}{l}\text { Stocking density of fishes } \\
\left(\text { no. }^{-1}{ }^{-1}\right)\end{array}$ & $\begin{array}{c}\text { Average area } \\
\text { (ha) }\end{array}$ \\
\hline $\mathrm{T}_{1}$ & \multirow[t]{3}{*}{ F } & Sarpunti & 40,000 & \multirow{3}{*}{0.02} \\
\hline $\mathrm{T}_{2}$ & & Sarpunti + Tilapia & $20,000+20,000$ & \\
\hline $\mathrm{T}_{3}$ & & $\begin{array}{c}\text { Sarpunti + Tilapia } \\
+ \text { Rui }\end{array}$ & $20,000+10,000+10,000$ & \\
\hline
\end{tabular}

Fortnightly sampling of $10-15 \%$ fishes was performed using a small seine net/cast net to ascertain fish weight and to adjust feeding ration. Growth was measured with digital balance (CAMRY digital electrical balance, Model EK 3052, Bangladesh) by weight. Behavior of fishes was regularly monitored especially after providing feed in the morning 
and in the evening to determine their conditions such as movement, infection, colorations and

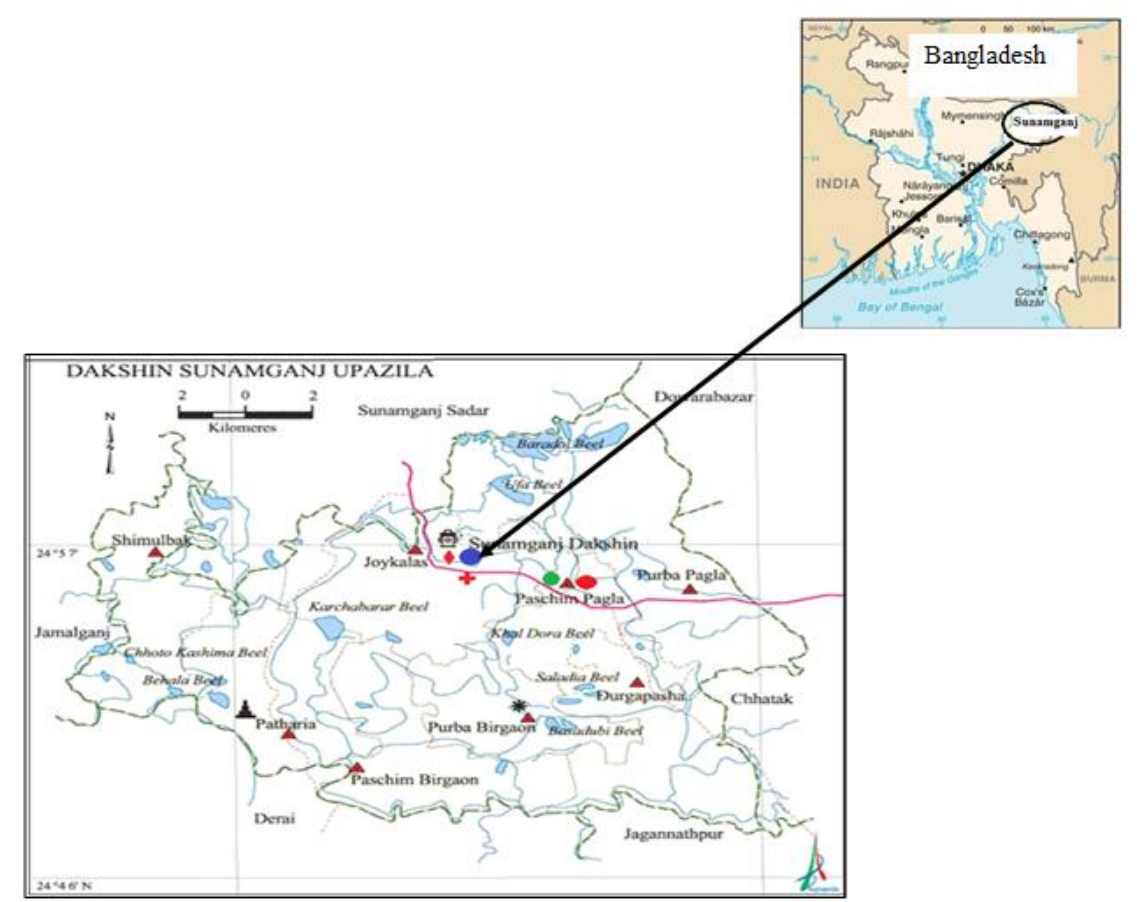

Fig. 1. Map of Dakshin Sunamganj upzila showing the study area.

Fishes were harvested after 120 days of culture. They were caught from each waterbody at the same day. At the end of the experiment, harvesting was done by total draining out of the waterbodies. After harvesting, all fishes of each waterbody were counted and weighed individually to calculate the growth, survival and production. Specific growth rate (SGR), food conversion ratio (FCR), survival (\%) and production (kg) were reckoned following the equation as cited by Pechsiri and Yakupitiyage [2].

The equations are as follows:

SGR (\%/day): $\{$ Ln (final body weight) - Ln (initial body weight) $\times 100\} /$ cultured period (day)

FCR: Feed consumed ( $\mathrm{g}$ dry weight)/Live weight gain ( $\mathrm{g}$ wet weight) of fish

Survival (\%): (Final number $\div$ Initial number) $\times 100$

Gross Yield $=$ No. of fish caught $\times$ average final weight

Net profit $=$ Total return - total cost

$\mathrm{BCR}=$ Total return/total cost

Growth, survival and production parameters were analyzed using one way analysis of variance (ANOVA) to compare the treatments means. If the main effect was found significant, the ANOVA was followed by Duncan's Multiple Range Test (DMRT). All 
ANOVA were tested at 5\% level of significance using SPSS (Statistical Package for Social Science) version 20.

\section{Results and Discussion}

\subsection{Water quality parameters}

Environmental parameters play an important role on the production of fish and other aquatic organisms. Suitable water quality parameters are pre-requisite for a healthy aquatic environment and for the production of sufficient fish and fish food. The primary productivity of a waterbody depends on the physical, chemical and other factors of water [3]. Water quality parameters of the studied waterbodies are depicted in Table 2.

Water depth was ranged from 90.0 to $130.0 \mathrm{~cm}$. Fluctuation in water depth was resulted due to evaporation, shower and water seepage. It was assumed that lower depth did not provide sufficient space for movement and feeding for cultured fish. The stocked fishes were suffered from temperature and other environmental parameters during winter period due to lower water depth (personal observation). Inadequate water depth is the most important factor for fin fishes/prawn/shrimp mortality [4,5].

Table 2. Water quality parameters (mean $\pm \mathrm{SD}$ ) recorded from the farmers' waterbodies in three treatments during the study period.

\begin{tabular}{llll}
\hline \multirow{2}{*}{ Parameters } & \multicolumn{2}{c}{ Treatments } \\
\cline { 2 - 4 } & $\mathrm{T}_{1}$ (Sarputi) & $\mathrm{T}_{2}$ (Sarputi + Tilapia) & $\mathrm{T}_{3}$ (Sarputi + Tilapia + Rui) \\
Water depth $(\mathrm{cm})$ & $90 \pm 8.9$ & $130 \pm 9.8$ & $110 \pm 10.8$ \\
Temperature $\left({ }^{\circ} \mathrm{C}\right)$ & $23.3 \pm 1.8$ & $22.9 \pm 3.9$ & $23.5 \pm 1.8$ \\
Transparency $(\mathrm{cm})$ & $24.2 \pm 1.48$ & $24.5 \pm 1.25$ & $23.8 \pm 1.52$ \\
$\mathrm{DO}\left(\mathrm{mgL}^{-1}\right)$ & $5.25 \pm 0.81$ & $4.9 \pm 0.79$ & $5.1 \pm 0.80$ \\
$\mathrm{pH}$ & 7.1 & 6.9 & 7.3 \\
Total alkalinity $\left(\mathrm{mgL}^{-1}\right)$ & $128.10 \pm 2.62$ & $125.11 \pm 2.70$ & $132.20 \pm 2.60$ \\
$\mathrm{NH}_{3}-\mathrm{N}\left(\mathrm{mgL}^{-1}\right)$ & $0.1 \pm 0.002$ & $0.05 \pm 0.001$ & $0.010 \pm 0.002$ \\
\hline
\end{tabular}

Temperature of water ranged between 22.9 and $23.5^{\circ} \mathrm{C}$ during rearing period of three species in waterbodies and found to be coincided to the observation of Roy and Wahab [6] and Dewan et al. [7] who recorded temperature ranges from 25.9 to $34.5^{\circ} \mathrm{C}$ in rearing of Chinese and Indian major carps and other small fish species at different densities in freshwater pond. Dissolved oxygen concentration varied from 4.9 to $5.25 \mathrm{mg} \mathrm{L}^{-1}$ was more or less similar to findings of Begum [8] who recorded DO ranges from 4.5 to 6.1 $\mathrm{mgL}^{-1}$ in research pond of Fisheries Faculty, Sylhet Agricultural University (SAU), Sylhet. The dissolved oxygen concentration under this study never fell to a critical level. The recorded DO level of the study was also within the suggested level (5.0 $\mathrm{mg} \mathrm{L}^{-1}$ or more) for fish culture [9]. Water transparency measured from $23.8-24.5 \mathrm{~cm}$ was agreed with the findings of Begum [8] who recorded mean transparency of $30.0 \pm 5.90 \mathrm{~cm}$ in research pond. Boyd [10] stated that suitable transparency range for fish culture is within 15-40 
$\mathrm{cm}$. The finding of the present study was matched with the findings of above mentioned authors.

Values of water $\mathrm{pH}$ varied from 6.9 to 7.3 in all treatments were similar to findings of Begum [8] who recorded $\mathrm{pH}$ of 7.2-7.5 in the research pond. Swingle [11] stated that the optimum range of $\mathrm{pH}$ 6.5-9.0 should be maintained for maximum growth and production of fish. Total alkalinity showed no significant difference $(\mathrm{p}>0.05)$ among the treatments. Fortnightly values of alkalinity were in the range of 125.11 to $132.20 \mathrm{mg} \mathrm{L}^{-1}$ in all the waterbodies. Mairs [12] reported that waterbodies having alkalinity $40 \mathrm{ppm}$ or more are considered more productive than waterbodies of lower alkalinity. So the findings of the present study were within suitable ranges. There was no treatment effect $(p>0.05)$ on overall mean concentrations of inorganic nutrients such as ammonia nitrogen. The concentrations of ammonia nitrogen in all treatments varied between 0.010 to $0.10 \mathrm{mg} \mathrm{L}^{-1}$. Begum [8] recorded $0.018 \mathrm{mg} \mathrm{L}^{-1}$ ammonia concentration in the SAU research pond. Meade [13] stated that the maximum safe concentration of ammonia level was unknown but he concluded that the permissible level was higher than the value of $0.012 \mathrm{mg} \mathrm{L}^{-1}$ commonly accepted by fish culturists. Ammonia values of the present study were within the accepted level $\left(>0.012 \mathrm{mgL}^{-1}\right)$.

\subsection{Growth and production performance of fishes}

As shown in Table 3, the values of growth, survival and production of fishes in different treatments of the study. Average body weight (ABW) of fry of sarpunti, tilapia and rui at stocking were 3.98, 4.11 and $4.07 \mathrm{~g}$, respectively in $\mathrm{T}_{1}, \mathrm{~T}_{2}$ and $\mathrm{T}_{3}$. The average final weight of sarpunti at harvest was $122.32 \pm 15.19,112.83 \pm 10.1$ and $102.5 \pm 9.87 \mathrm{~g}$ in $\mathrm{T}_{1}$, $\mathrm{T}_{2}$ and $\mathrm{T}_{3}$, respectively. The highest and lowest weight gained by tilapia was $102.58 \pm 23.22$ and $75.33 \pm 15.99 \mathrm{~g}$ in $\mathrm{T}_{2}$ and $\mathrm{T}_{3}$, respectively. The growth of rui was $140.3 \pm 27.56 \mathrm{~g}$ in $\mathrm{T}_{3}$, which was significantly different from others two treatments. Shofiquzzoha and Das [14] stated that the final weight of Thai koi, silver barb (raj punti) and BFRI GIFT was 28.00-38.00, 117.00-134.00 and 142.00-222.50 g, respectively after 120 days rearing (April-July) in the seasonal ditches of Saidpur, Nilphamari. Islam et al. [15] reported that the average weight of tilapia was 90-200 g for 210 days (June-December) at the seasonal ditches in 3 treatments under polyculture of silver carp, common carp and tilapia at Farming System Research (FSR) site, Palima, Tangail. Islam et al. [16] also stated that average weight of sarpunti recorded of 85.0-175.0 g for 180 days (July-December) at the seasonal ditches in 3 treatments under mixed culture of sarpunti and common carp at Palima FSR site. The findings of the present study were more or less coincided with the findings of the above authors. Depth of water of studied farms fluctuated from 90.0 to $130.0 \mathrm{~cm}$ during the culture period, which was normally not favorable of carp species rui [17]. But growth of rui was good in the seasonal waterbodies. It was assumed that there was strong competition for feed and space among three species due to low water depth. For this reason, growth of tilapia was low in $\mathrm{T}_{3}$ compared to other treatments. 
Supplementary feed was provided with different ratio for all species and the survival was not equally proportionate to the density (Table 3 ).

Survival of tilapia was $67.9 \pm 9.09$ and $75.33 \pm 10.87 \%$ in $\mathrm{T}_{2}$ and $\mathrm{T}_{3}$, respectively which was lower than sarputi and rui. Survival of sarpunti was 75.8 $\pm 5.98,70.50 \pm 5.87$ and $65.2 \pm 4.81 \%$ in $T_{3}, T_{1}$ and $T_{2}$, respectively while for rui it was $83.1 \pm 10.45 \%$ in $T_{3}$. Shofiquzzoha and Das [14] reported that survival of silver barb and GIFT was found to range from $67.40-76.19 \%$ and $71.33-78.44 \%$, respectively for 120 days in different treatments in seasonal ponds at Saidpur. Islam et al. [15] stated that survival of tilapia was 82.0-92.0\% for 210 days at the seasonal ditches in 3 treatments under polyculture of silver carp, common carp and tilapia at Palima FSR site. Islam et al. [16] reported that survival of sarpunti was 52.0-72.0\% for 180 days (July-December) at the seasonal ditches in 3 treatments under mixed culture of sarpunti and common carp at Palima FSR site, which were supported to the findings of the present study. Besides, the survival of the present study was also similar as reported by Adhikary et al. [18], Ahmed and Khair [19], Begum et al. [20] and Shah et al. [21]. The specific growth rate (SGR) of sarpunti, tilapia and rui was 3.42-3.66, 3.14-3.45 and 3.78 which was lower than the findings of Shofiquzzoha and Das [14] who recorded the SGR of silver barb and GIFT ranges from 5.42 to 5.56 and 5.02 to 5.47, respectively. Uddin et al. [22] reported that the range of SGR of tilapia was $2.87-3.09 \%$, which was slightly lower than the findings of the present study.

Food conversion ratio (FCR) depends on supplied food and water quality. In the present study the FCR of sarpunti was $1.26,1.38$ and 1.52 in $\mathrm{T}_{1}, \mathrm{~T}_{2}$ and $\mathrm{T}_{3}$, respectively. FCR of tilapia was 1.52 and 2.11 in $\mathrm{T}_{2}$ and $\mathrm{T}_{3}$, respectively and in case of rui it was 1.10 in $T_{3}$, which was lowest than that of sarpunti and tilapia (Table 3). It might be due to rui utilized the supplementary feed very efficiently. The finding of the study was similar to the findings of Shofiquzzoha and Das [14] who recorded FCR of silver barb and GIFT ranges from 1.41 to 1.87 and 1.41 to 1.85 , respectively.

After 120 days of culture, the production of sarpunti, tilapia and rui in $T_{1}, T_{2}$ and $T_{3}$ were significantly different from each treatment. The range of sarpunti production was 2,804.80-3,446.13 kg ha ${ }^{-1}$ where higher production was obtained in $\mathrm{T}_{1}\left(3,446.13 \mathrm{~kg} \mathrm{ha}^{-1}\right)$ than $\mathrm{T}_{3}\left(2804.10 \mathrm{~kg} \mathrm{ha}^{-1}\right)$ and $\mathrm{T}_{2}\left(2,942.60 \mathrm{~kg} \mathrm{ha}^{-1}\right)$. Higher production of tilapia was achieved in $\mathrm{T}_{2}\left(2,786.07 \mathrm{~kg} \mathrm{ha}^{-1}\right)$ than $\mathrm{T}_{3}\left(2,172.52 \mathrm{~kg} \mathrm{ha}^{-1}\right)$ in winter season and the production of rui was $3,364.8 \mathrm{~kg} \mathrm{ha}^{-1}$, which was higher than the production of other two fishes (sarpunti and tilapia). Kohinoor et al. [23] reported that the production of tilapia was recorded from $1,852.5$ to $2,223.0 \mathrm{~kg} \mathrm{ha}^{-1}$ in polyculture of koi, shing and tilapia for 120 days in the seasonal ponds, which was lower than the findings of the present study. Shofiquzzoha and Das [14] mentioned that the production of silver barb and GIFT was found $1,355.58-1,997.14 \mathrm{~kg} \mathrm{ha}^{-1}$ and 2,532.11-4,551.89 $\mathrm{kg} \mathrm{ha}^{-1}$, respectively for 120 days in 3 treatments in the seasonal ponds under polyculture of koi, silver barb and GIFT in warm season. The finding of present study was higher than the finding of Gupta and Rab [24], who found $772 \mathrm{~kg} \mathrm{ha}^{-1}$ of silver barb for 90 days in the seasonal waterbodies at farmers' level. The highest combined yield of fishes was obtained in $T_{3}(8,341.41 \pm$ 
$\left.509.83 \mathrm{~kg} \mathrm{ha}^{-1}\right)$ followed by $\mathrm{T}_{2}\left(5,728.67 \pm 253.32 \mathrm{~kg} \mathrm{ha}^{-1}\right)$ and $\mathrm{T}_{1}(3,446.13 \pm 189.99 \mathrm{~kg}$ $\left.\mathrm{ha}^{-1}\right)$. Islam et al. [15] stated that the combined production of silver carp, common carp and tilapia was found ranges from 951.67-2,966.30 $\mathrm{kg} \mathrm{ha}^{-1}$, which was much lower than the findings of the present study. The findings of the study was higher than the findings of Islam et al. [16], who recorded the combined production of sarpunti and silver carp ranges from 1,123.66-3,456.00 $\mathrm{kg} \mathrm{ha}^{-1}$ in the seasonal ditches. The combined production of the present study was comparatively lower than the combined production $\left(23,094.25 \mathrm{~kg} \mathrm{ha}^{-1}\right)$ of koi, shing and tilapia in polyculture system at on-station ponds as reported by Kohinoor et al. [23].

Table 3. Growth, survival and production (mean \pm SD) of Puntius gonionotus, Oreochromis niloticus and Labeo rohita in three treatments during the study period.

\begin{tabular}{|c|c|c|c|}
\hline \multirow{2}{*}{$\begin{array}{l}\text { Fish species and } \\
\text { production parameters }\end{array}$} & \multicolumn{3}{|l|}{ Treatments } \\
\hline & $\mathrm{T}_{1}$ (Sarpunti) & $\mathrm{T}_{2}$ (Sarpunti+ Tilapia) & $\mathrm{T}_{3}$ (Sarpunti+ Tilapia+ Rui) \\
\hline \multicolumn{4}{|l|}{ Sarputi } \\
\hline Av. initial weight (g) & $3.98 \pm 1.25$ & $4.12 \pm 1.30$ & $4.11 \pm 1.20$ \\
\hline Av. final weight (g) & $122.32 \pm 15.19$ & $112.83 \pm 10.1$ & $102.5 \pm 9.87$ \\
\hline Weight gain $(\mathrm{g})$ & $118.34 \pm 13.94^{\mathbf{a}}$ & $108.33 \pm 8.8^{\mathbf{a b}}$ & $98.27 \pm 8.67^{\mathbf{b}}$ \\
\hline SGR & 3.66 & 3.47 & 3.42 \\
\hline Survival (\%) & $70.5 \pm 5.87^{\mathbf{a}}$ & $65.2 \pm 4.81^{\mathbf{a}}$ & $75.8 \pm 5.98^{\mathbf{b}}$ \\
\hline FCR & $1.26^{\mathrm{c}}$ & $1.38^{\mathbf{b}}$ & $1.52^{\mathbf{a}}$ \\
\hline Production $\left(\mathrm{kgha}^{-1}\right)$ & $3,446.13 \pm 189.99$ & $2,942.6 \pm 150.45$ & $2,804.8 \pm 160.54$ \\
\hline \multicolumn{4}{|l|}{ Tilapia } \\
\hline Av. initial weight (g) & & $4.1 \pm 1.19$ & $4.1 \pm 1.25$ \\
\hline Av. final weight (g) & & $102.58 \pm 23.22^{\mathrm{a}}$ & $75.33 \pm 15.99^{b}$ \\
\hline Weight gain $(\mathrm{g})$ & & $98.48 \pm 22.03^{\mathrm{a}}$ & $70.9 \pm 14.74^{\mathbf{b}}$ \\
\hline SGR & & 3.45 & 3.14 \\
\hline Survival (\%) & & $67.9 \pm 9.09$ & $75.33 \pm 10.87$ \\
\hline FCR & & $1.52^{\mathbf{b}}$ & $2.11^{\mathbf{a}}$ \\
\hline Production $\left(\mathrm{kgha}^{-1}\right)$ & & $2,786.07 \pm 102.87$ & $2,172.52 \pm 99.11$ \\
\hline \multicolumn{4}{|l|}{ Rui } \\
\hline Av. initial weight (g) & & & $4.07 \pm 1.30$ \\
\hline Av. final weight (g) & & & $140.3 \pm 27.56$ \\
\hline Weight gain $(\mathrm{g})$ & & & 136.3 \\
\hline SGR & & & 3.78 \\
\hline Survival (\%) & & & $83.1 \pm 10.45$ \\
\hline FCR & & & 1.10 \\
\hline Production $\left(\mathrm{kgha}^{-1}\right)$ & & & $3,364.8 \pm 250.18$ \\
\hline $\begin{array}{l}\text { Combined production } \\
\left(\mathrm{kgha}^{-1} 120^{-1} \text { days }\right)\end{array}$ & $3,446.13 \pm 189.99^{\mathbf{c}}$ & $5,728.67 \pm 253.32^{\mathbf{b}}$ & $8,341.41 \pm 509.83^{\mathbf{a}}$ \\
\hline
\end{tabular}

Mean values in the same row with same superscript letters are not significantly different $(\mathrm{p}>0.05)$.

After 120 days of fish farming, the net profits $\left(\mathrm{Tk} . \mathrm{ha}^{-1}\right)$ obtained from present study under three treatments were 64,750 $\pm 3,458\left(\mathrm{~T}_{1}\right), 117,000 \pm$ 7,349 $\left(\mathrm{T}_{2}\right)$ and Tk. 288,000 \pm $11,293\left(\mathrm{~T}_{3}\right) \mathrm{ha}^{-1}$, respectively. Significantly $(\mathrm{p}<0.05)$ higher profit was obtained in $\mathrm{T}_{3}(\mathrm{Tk}$. 
$228,000 \pm 11,293)$ than those of $\mathrm{T}_{1}(\mathrm{Tk} .64,750 \pm 3,458)$ and $\mathrm{T}_{2}$ (Tk. 117,000 $\left.\pm 7,349\right)$. The highest cost benefit ratio was achieved in $T_{3}(1: 1.64)$ than that of $T_{1}(1: 1.25)$ and $T_{2}$ (1:1.30) (Fig. 2).

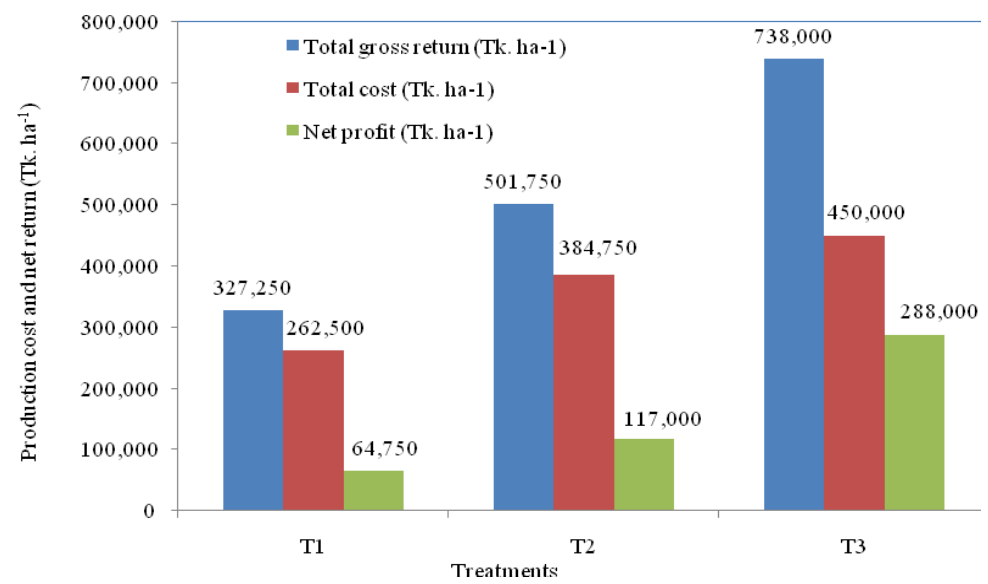

Fig. 2. Production cost and net return of fish production in different treatments.

Considering growth, survival and production it may be implied that the seasonal waters can be effectively used for polyculture of fast growing fish species in haor region. Among different techniques of aquaculture, polyculture is one of the most important techniques. The farmers of the hoar region believe that these waters could not be utilized for fish production purpose due to its seasonal nature. But actually these waterbodies hold hold tremendous potential for adopting improved culture techniques of fishes having short cycle, fast grower, hardy, diseases resistant and survive in adverse conditions, high nutritive value as well as high market price. Technical know-how about the fish culture in seasonal ponds would help the resource poor farmers to improve their livelihood and income generation.

\section{Acknowledgments}

The authors highly acknowledge to Krishi Gobeshona Foundation (KGF), Bangladesh Agricultural Research Council (BARC), Farmgate, Dhaka for providing fund to conduct the research under the project entitled "Farm Productivity Improvement in Haor areas through Integrated Farming Systems Approach".

\section{References}

1. DoF (Department of Fisheries), National Fish Week Compendium (In Bengali). Ministry of Fisheries and Livestock (Dhaka, Bangladesh, 2016) pp.148

2. J. Pechsiri and A. Yakupitiyage, Aquacult. Res. 36, 45 (2005).

3. M. S. Rahman, M. Y. Chowdhury, A. K. M. A. Haque, and M. S. Haq, Bangladesh J. Fish. 2-5, 25 (1982). https://doi.org/10.1111/j.1365-2109.2004.01182.x 
4. M. R. Karim, Environmental and Socioeconomic Impacts of Shrimp Farming in Bangladesh, BRAC Centre (Mohakhali, Dhaka, Bangladesh, 2002).

5. M. S. Islam, Y. Mahmud, and A. M. O. Faruque, Bangladesh J. Fish. Res. 12(2), 205 (2008).

6. H. C. Roy and M. A. Wahab - Proc. of 5th Fisheries Conference \& Research Fair, 2012 (Bangladesh Agricultural Research Council, Bangladesh Fisheries Research Forum, Dhaka, Bangladesh, 2014) pp. 246.

7. S. Dewan, M. A. Wahab, M. C. M. Beveridge, M. H. Rahman, and B. K. Sarker, J. Aquaculture Res. 22(3), 277 (1991). https://doi.org/10.1111/j.1365-2109.1991.tb00518.x

8. N. Begum, MS Thesis, (Sylhet Agricultural University, Sylhet (2015).

9. C. E. Boyd, Alabama: Alabama Agricultural Experiment Station (Auburn University, Auburn, 482, 1990).

10. C. E. Boyd, The Netherlands (Elsevier Science Publishers B.V., Amsterdam, 1982).

11. H. S. Swingle, FAO Fisheries Report 4(2), 397 (1969).

12. D. F. Mairs, Limno. Oceanogr. 11, 68 (1966).

13. J. W. Meade, Prog. Fish Cult. 47, 135 (1985). https://doi.org/10.1577/1548-8640(1985)47<135:AAFFC >2.0.CO;2

14. F. M. Shofiquzzoha and D. R. Das, Bangladesh J. Agri. 37(1), 71 (2012).

15. M. S. Islam, M. A. Ali, and M. A. Mazid, Bangladesh J. Train. Devt. 10(1-2), 175 (1997).

16. M.S. Islam, M. E. Azim, M. M. Rahman, and M. A. Mazid, J. Progress. Agric. 8(1-2), 191 (1997).

17. M. A. Karim, MS Thesis, Bangladesh Agricultural University, Bangladesh (1975).

18. R. K. Adhikary, Z. B. Mostofa, A. Saha, and M. S. Shah, Bangladesh Res. Pub. J. 2(1), 361 (2009).

19. M. T. Ahmed and M. A. Khair, A Fish Fortnight Compendium - Conservation and Extension Movement for Indigenous Fish Species, (in Bangla). (Ministry of Fisheries and Livestock, Bangladesh, 2007) pp. 51-52

20. A. Begum, G. Mustafa, and K. Ahmed, Bangladesh J. Zool. 17(1), 35 (2003).

21. A. K. M. A. Shah, M. A. Hossain, and K. Afsana, Bangladesh J. Fish. 2-2(2), 159 (1998).

22. M. S. Uddin, A. Farzana, M. K. Fatema, M. E. Azim, M. A. Wahab, and M. C. J. Verdegem, Aquaculture 269(1-4):232 (2007).

23. A. H. M. Kohinoor, M. S. Islam, and M. M. Rahman, Fish Week Publication No. 8.

(Bangladesh Fisheries Research Institute, Bangladesh, 2016). P.56

24. V. M. Gupta and M. A. Rab, ICLARM Tech. Rep. 41, 39 (1994). 